\title{
Microsite effects on abundance of sown species on uncultivable slopes
}

\author{
G.B. DOUGLAS ${ }^{1}$, R.A. MOSS ${ }^{2}$, T.L. KNIGHT ${ }^{2}$, C.M. LLOYD-WEST ${ }^{1}$, R. GRAY ${ }^{1}$ and K.N. TOZER ${ }^{3}$ \\ ${ }^{1}$ AgResearch Grasslands, Private Bag 11008, Palmerston North 4442, New Zealand \\ ${ }^{2}$ AgResearch Lincoln, Private Bag 4749, Christchurch 8140, New Zealand \\ ${ }^{3}$ AgResearch Ruakura, Private Bag 3123, Hamilton 3214, New Zealand
}

grant.douglas@agresearch.co.nz

\begin{abstract}
Hill country has a vast array of microsites that may influence the success and uniformity of establishment of oversown pasture species and their persistence. In spring 2014, studies were conducted at Woodville (southern Hawke's Bay; summer-wet) and Cheviot (North Canterbury; summer-dry) to determine the effect of gentle $\left(14-21^{\circ}\right)$ and steep $\left(32-40^{\circ}\right)$ slopes on the presence and contribution to sward dry matter (DM) of oversown species in rotationally grazed swards aged 30 or 36 months. Gentle slopes had greater soil water content (29 versus $25 \%$ ) and Olsen P (34 versus $26 \mu \mathrm{g}$ / $\mathrm{ml})$ than nearby steep slopes. Perennial ryegrass $(94$ versus $80 \%$ ) and phalaris (6 versus $2 \%$ ) were present in a greater proportion of plots on gentle than on steep slopes, respectively, whereas subterranean clover had a greater presence on steep than on gentle slopes (6 versus $1 \%)$. Perennial ryegrass comprised a higher percentage of DM in swards on gentle than on steep slopes (27 versus $11 \%$ ). The percentage of DM contributed by other individual species did not differ significantly between slope classes. The persistence of most sown species was unaffected by slope; microsite variation was not a major influence on species persistence.
\end{abstract}

Keywords: hill country, microsites, pasture species, plant-microsite matches

\section{Key messages}

- Gentle slopes had greater Olsen P (34 versus $26 \mu \mathrm{g} /$ $\mathrm{ml}$ ) and volumetric soil water content (29 versus $25 \%$ ) than adjacent steep slopes in spring.

- Perennial ryegrass had greater presence (94 versus $80 \%$ ) and comprised a higher percentage of dry matter in swards (27 versus $11 \%$ ) on gentle than steep slopes.

- The persistence of most sown species under rotational grazing after 30 or 36 months was unaffected by micro-scale differences in slope.

\section{Introduction}

There is a wide range of pasture species and cultivars adapted to different environmental conditions (Stewart et al. 2014) and a number of these have been evaluated in uncultivable hill country ( $>25^{\circ}$ slope) over decades e.g. Chapman \& Macfarlane (1985), Lambert et al. (1985), Scott et al. (1985) and Hampton et al. (1999). New cultivars of long-used species such as perennial ryegrass, cocksfoot, white clover, and red clover continue to be released and there has been increasing use of newer species such as plantain and chicory in seed mixes oversown on hill country. Variation between the myriad of microsites in hill country can result in non-uniform seedling establishment of sown species. Lambert et al. (1985) highlighted the potential value of introducing new germplasm to exploit the many different microsites and to allow for situations where germplasm in earlier oversowings established but did not persist, perhaps because of inappropriate management.

Establishment trials with a range of species and cultivars were commenced on uncultivable hill country throughout New Zealand in 2011/12 (Douglas et al. 2013; Tozer et al. 2013; Tozer et al. 2014). Moderate to steep hill country is characterised frequently by development of microsites such as areas of gentle (treads) and steep (scarps) slope angles depending on factors such as the extent and age of shallow landsliding, and stock grazing pressures and movement. This study aimed to determine the effect of gentle and steep slopes on the presence of sown species and botanical composition in established swards. A further aim was to link plant and microsite environmental attributes to obtain greater understanding of interactions.

\section{Materials and methods \\ Sites}

Study sites were on uncultivable hill country near Woodville, southern Hawke's Bay, and Cheviot, North Canterbury. Woodville is a summer-wet environment with long-term (25 year) summer rainfall (December to February) of $177 \mathrm{~mm}$ and Cheviot is a summer-dry environment (127 $\mathrm{mm}$, equivalent data).

\section{Treatments}

Four test swards and the resident sward (unsown, control) were selected in spring 2014, with the test swards aged 30 or 36 months. The test swards originated from oversowing a grass, legume and herb seed mix $(\mathrm{GLH})$ in spring 2011 (sprGLH) and autumn 2012 (autGLH), and a legume-only seed mix (LEG) in spring 2011 (sprLEG) 
and autumn 2012 (autLEG) (Tozer et al. 2013; Tozer et al. 2014). The GLH mix comprised perennial ryegrass (Lolium perenne), cocksfoot (Dactylis glomerata), phalaris (Phalaris aquatica), grazing brome (Bromus stamineus), white clover (Trifolium repens), red clover (T. pratense), subterranean clover (T. subterraneum), plantain (Plantago lanceolata) and chicory (Cichorium intybus). The LEG mix comprised white clover, red clover, subterranean clover, birdsfoot trefoil (Lotus corniculatus) and lotus (Lotus uliginosus syn. L. pedunculatus). Cultivars and sowing rates are specified elsewhere (Tozer et al. 2013; Tozer et al. 2014). Each sward plot (experimental unit) was $10 \times 10 \mathrm{~m}$. Since sward establishment, all plots had been grazed 4- to 9-weekly with mixed-age sheep.

At Woodville, three replicate plots of the treatments were selected on the north and south aspects, whereas at Cheviot, three replicate plots of each treatment were selected only on the north aspect because this was the only aspect with variation in micro-slope angle. Within all selected plots, gentle (14-21 ${ }^{\circ}$ slope angle) and steep $\left(32-40^{\circ}\right)$ slopes were identified. Grazing ceased at Woodville on 6 October and at Cheviot on 5 November 2014.

\section{Measurements}

Herbage mass and botanical composition were determined at Woodville on 10 November (35 days after last grazing) and at Cheviot on 8 December (33 days). Herbage was harvested to ground level $(<5 \mathrm{~mm}$ height) in four quadrat areas of $0.1 \mathrm{~m}^{2}(250 \mathrm{~mm} \times 400 \mathrm{~mm})$ per plot, comprising two quadrats on each of gentle and steep slopes. Herbage was subsampled for dissection into categories of individual sown grasses, individual sown legumes, individual sown herbs, other grasses, other legumes, weeds and dead matter. All components and remainder were oven-dried $\left(24 \mathrm{~h}\right.$ at $\left.70^{\circ} \mathrm{C}\right)$. Growth rate of swards at each site was determined by harvesting herbage at the start (pre-growth) and end of the studies (Douglas et al. 2015).

Each quadrat area was measured for slope angle, aspect, volumetric soil water content (VSWC, 0-75 $\mathrm{mm}$ soil depth; mean of 5 readings), and soil chemistry (0-75 mm depth; bulked 8-10 cores each $25 \mathrm{~mm}$ diameter) comprising $\mathrm{pH}(1: 2.1 \mathrm{v} / \mathrm{v}$ water slurry), Olsen phosphate (P, Olsen extraction), sulphate sulphur ( $\mathrm{SO}_{4}$-S; phosphate extraction), and 'Quick test' calcium $(\mathrm{Ca})$, potassium $(\mathrm{K})$, magnesium $(\mathrm{Mg})$ and sodium $(\mathrm{Na})$ using ammonium acetate extraction (Douglas et al. 2015).

\section{Statistical analyses}

Data for herbage mass, sward growth rate, VSWC, and soil chemical attributes were analysed using a splitplot analysis of variance in Genstat (VSN International
2014). Mean separation was achieved using Least Significant Difference (LSD) tests. Data were transformed where necessary and back-transformed means are presented to aid understanding.

There was a 2-stage analysis of the species data. Firstly, the presence/absence of each sown species in plots of the test swards, and the same species in plots of the resident swards, was determined assuming a binomial distribution with logit link function. Secondly, the percentage of each species in dry matter (DM) of swards was analysed using analysis of variance. For sown species where the data comprised many or all zeroes in specific factor combinations, those combinations were excluded from the analysis.

Separate canonical correlation analyses (Digby \& Kempton 1987) were conducted for the Woodville and Cheviot studies using data for environmental parameters (slope, aspect, VSWC, soil chemistry attributes) and plant attributes (growth rate, masses of key sown species, other grasses, weeds, and dead matter) collected from control and GLH swards.

\section{Results}

\section{Environmental parameters}

Angles of steep slopes were almost twice those of gentle slopes on northern aspects at Woodville (WNTH; 40 versus $21^{\circ}$ ) and Cheviot (CNTH; 32 versus $18^{\circ}$ ), and 2.6-fold greater on the south aspect at Woodville (WSTH; 37 versus $14^{\circ}$ ). Aspects of gentle and steep slopes were similar within location $\times$ aspect combinations (not presented).

The late spring moisture content at Cheviot $(11 \%$ $\mathrm{v} / \mathrm{v}$ ) was considerably less than at Woodville (WNTH $=31 \%$; WSTH $=46 \%)$. Soil $\mathrm{pH}$ was $5.2(\mathrm{WNTH}), 5.3$ (WSTH) and $5.5(\mathrm{CNTH})$ and Olsen P ranged from 27 $\mu \mathrm{g} / \mathrm{ml}$ (CNTH) to $36 \mu \mathrm{g} / \mathrm{ml}$ (WNTH). Levels of $\mathrm{SO}_{4}$-S at Cheviot (6 ppm) were about half those at Woodville, and $\mathrm{K}$ levels at Cheviot (24 Quick test units) were 4-fold greater than those at Woodville.

Gentle slopes had greater VSWC (29 versus 25\%) and Olsen P (34 versus $26 \mu \mathrm{g} / \mathrm{ml}$ ) than steep slopes. Results for $\mathrm{pH}, \mathrm{SO}_{4}-\mathrm{S}, \mathrm{Ca}, \mathrm{K}$ and $\mathrm{Mg}$ were inconsistent (location $\times$ aspect $\times$ slope interaction; $\mathrm{P}<0.05$ ). For example, $\mathrm{SO}_{4}-\mathrm{S}$ was greater on gentle than steep slopes at WSTH (12.3 versus $9.4 \mathrm{ppm}$ ) and CNTH (6.2 versus $5.5 \mathrm{ppm})$ whereas at WNTH, steep slopes had greater $\mathrm{SO}_{4}-\mathrm{S}$ levels than gentle slopes (13.3 versus $11.8 \mathrm{ppm}$ ).

\section{Herbage mass and growth rate}

Herbage mass averaged 5.1 tonnes DM/ha at WNTH, 4.0 tonnes $\mathrm{DM} / \mathrm{ha}$ at $\mathrm{WSTH}$, and 3.5 tonnes $\mathrm{DM} / \mathrm{ha}$ at CNTH. Sward growth rates at Woodville were $53 \mathrm{~kg}$ $\mathrm{DM} / \mathrm{ha} /$ day on WNTH and $32 \mathrm{~kg} \mathrm{DM} /$ ha/day on WSTH, exceeding those at CNTH (13 kg DM/ha/day). Herbage mass on gentle slopes was about 1.3-fold greater than 
on steep slopes (4.8 versus 3.6 tonnes $\mathrm{DM} / \mathrm{ha} ; \mathrm{P}<0.001$ ) and growth rate of swards on gentle slopes was twice that on steep slopes (44 versus $22 \mathrm{~kg} \mathrm{DM} / \mathrm{ha} /$ day).

\section{Contribution of sown species}

Perennial ryegrass was the only sown species present in at least $75 \%$ of plots and at $\mathrm{CNTH}$, it was present in nearly all plots (Table 1). Presence of perennial ryegrass at $\mathrm{WNTH}$ and $\mathrm{CNTH}$ was significantly greater than at WSTH. Presence of cocksfoot was in the order WNTH $>$ WSTH $>$ CNTH. Grazing brome and phalaris were present in less than $10 \%$ of plots. Among sown legumes, white clover had the highest presence (62$80 \%$ ). Red clover was present in approximately a quarter of plots at CNTH and negligible (WSTH) or absent (WNTH) elsewhere. Subterranean clover was detected in $10 \%$ of plots at CNTH and was absent at Woodville. Half the plots at WSTH contained Lotus spp. which was 5-fold greater than at CNTH. At least 4-fold more plots had chicory and plantain at CNTH than at Woodville (Table 1). Perennial ryegrass and phalaris were present in a greater proportion of plots on gentle than steep slopes whereas subterranean clover had 6-fold greater presence on steep than gentle slopes (Table 1). Slope had no effect on the presence of any other sown species. Results for individual swards are presented in Douglas et al. (2015).

Total sown species comprised the greatest percentage of sward DM at CNTH (26\%), which was approximately twice that at WNTH and 4-fold greater than at WSTH. At WNTH, total sown species content in swards on gentle slopes was 3-fold greater than on steep slopes (26 versus $8 \% \mathrm{DM}$ ), whereas at WSTH (8 versus $5 \%$ $\mathrm{DM}$ ) and CNTH (30 versus $23 \% \mathrm{DM}$ ), contents of total sown species on gentle and steep slopes were similar (location $\times$ aspect $\times$ slope interaction; $\mathrm{P}=0.014$ ). The content of perennial ryegrass in swards was the highest of any sown species and at CNTH it was about 2-fold greater than at WNTH and 4-fold greater than at WSTH. The control sward at Woodville had an average content ( $\%$ of DM) of $12 \%$ perennial ryegrass, $2 \%$ cocksfoot, $2 \%$ white clover, $1.5 \%$ Lotus spp. and $0.1 \%$ plantain. At Cheviot, content averaged $39 \%$ perennial ryegrass, $1 \%$ Bromus spp., $1 \%$ subterranean clover and $0.1 \%$ plantain. Across all swards, those on gentle slopes at WNTH had greater perennial ryegrass content than on steep slopes (30 versus 3\% DM) whereas there were smaller differences in content between slope classes at WSTH (12 versus 5\% DM) and CNTH (37 versus 26\% $\mathrm{DM})$ (location $\times$ aspect $\times$ slope interaction; $\mathrm{P}=0.009$ ). Sward contents of other sown species were less than $5 \%$ of DM at all locations (Douglas et al. 2015).

The first canonical correlation at Woodville was 0.80 $(\mathrm{P}<0.001)$ and accounted for $23 \%$ of the total correlation between the environmental and plant datasets. Of the key attributes in the first canonical variates for each dataset, higher values of $\mathrm{K}$, growth rate and mass of perennial ryegrass, and lower values of Olsen $\mathrm{P}$ and slope, tended to occur on gentle slopes (Figure 1a). Results for a significant second correlation are not presented because the variate for the plant dataset did not involve any sown species. At Cheviot, the first canonical correlation was $0.96(\mathrm{P}<0.01)$ and accounted for $16 \%$ of the total correlation between the environmental and plant datasets. Higher values of aspect, Olsen P, K, Na, and masses of perennial ryegrass and dead matter tended to occur on gentle slopes (Figure 1b). Other canonical correlations were not significant.

\section{Discussion}

The 3- or 4-fold greater pasture growth rates (only one growth period) at Woodville than at Cheviot were

Table 1 Proportion of plots with sown species present (\%), across three location $\times$ aspect combinations.

\begin{tabular}{|c|c|c|c|c|c|c|c|c|c|c|}
\hline & $\begin{array}{c}\text { Perennial } \\
\text { ryegrass } \\
(\%)\end{array}$ & $\begin{array}{c}\text { Cocksfoot } \\
\text { (\%) }\end{array}$ & $\begin{array}{c}\text { Grazing } \\
\text { brome } \\
(\%)\end{array}$ & $\begin{array}{c}\text { Phalaris } \\
(\%)\end{array}$ & $\begin{array}{c}\text { White } \\
\text { clover } \\
(\%)\end{array}$ & $\begin{array}{l}\text { Red } \\
\text { clover } \\
(\%)\end{array}$ & $\begin{array}{c}\text { Subterranean } \\
\text { clover } \\
(\%)\end{array}$ & $\begin{array}{l}\text { Lotus } \\
\text { spp. } \\
(\%)\end{array}$ & $\begin{array}{c}\text { Chicory } \\
(\%)\end{array}$ & $\begin{array}{c}\text { Plantain } \\
(\%)\end{array}$ \\
\hline \multicolumn{11}{|l|}{ Location $\times$ aspect } \\
\hline Woodville - North & $89 a^{1}$ & $75 a$ & 3 & $3 b$ & 80 & $\mathrm{Ob}$ & $\mathrm{Ob}$ & $31 a b$ & $3 b$ & $6 b$ \\
\hline Woodville - South & $75 b$ & $47 \mathrm{~b}$ & 3 & $\mathrm{Ob}$ & 62 & $3 b$ & $\mathrm{Ob}$ & $50 a$ & $6 a b$ & $11 b$ \\
\hline Cheviot - North & $97 a$ & $22 c$ & 8 & $8 a$ & 67 & $27 a$ & $10 a$ & $11 b$ & $25 a$ & $39 a$ \\
\hline$P$ value ${ }^{2}$ & 0.006 & $<0.001$ & 0.085 & $<0.001$ & 0.157 & $<0.001$ & $<0.001$ & 0.012 & $<0.001$ & $<0.001$ \\
\hline \multicolumn{11}{|l|}{ Slope } \\
\hline Gentle & $94 a$ & $N A^{3}$ & 4 & $6 a$ & 71 & 11 & $1 b$ & 26 & 13 & 22 \\
\hline Steep & $80 \mathrm{~b}$ & NA & 6 & $2 b$ & 68 & 9 & $6 a$ & 35 & 9 & 15 \\
\hline$P$ value & 0.007 & NA & 0.402 & 0.047 & 0.677 & 0.397 & $<0.001$ & 0.361 & 0.411 & 0.252 \\
\hline
\end{tabular}

${ }^{1}$ means with different letters differ at $5 \%$ level

${ }^{2} \mathrm{P}=$ probability

${ }^{3}$ Not available because of computer analysis limitations 
probably because of the relatively high soil water content found at Woodville rather than slight differences between sites in soil chemistry. The water content at Cheviot was likely near wilting point. Temperature might have also been influential given the difference in latitude between the sites, although in November/ December, this effect was likely small. Soil $\mathrm{pH}$ at the three location $\times$ aspect combinations and $\mathrm{SO}_{4}-\mathrm{S}$ at CNTH were less than recommendations of 5.8-6.0 for $\mathrm{pH}$ and 10-12 ppm for $\mathrm{SO}_{4}-\mathrm{S}$ (Morton \& Roberts 2009), but these were unlikely to have explained the variation in growth rates.

Results were dominated by those for perennial ryegrass with the species being present in the highest proportion of plots and its content in herbage DM being greater than for any other sown species. It also showed a preference for gentle compared with steep slopes, probably because of their greater soil water content and greater soil $\mathrm{P}$ status. The low presence and sward content of grazing brome, phalaris and subterranean clover suggested that these species were only likely to be small contributors to sward DM in grazed, multi-species pastures in the longer term. At Woodville, the greatest presence and sward content of cocksfoot at WNTH and of Lotus spp. at WSTH suggested that it would be beneficial to add cocksfoot to seed mixes for northern aspects and Lotus spp. for southern aspects. It is recommended that red clover, chicory and plantain be included in seed mixes used in summer-dry environments because at Cheviot they were in at least $25 \%$ of plots in which they were sown, and they had greater contents in swards than at Woodville. Although red clover, chicory and plantain did not persist at Woodville as well as at Cheviot, there are numerous red and white clover and plantain pastures that have been established successfully on North Island hill country in the past few years.

The association between increasing slope angle and decreasing growth rate and mass of perennial ryegrass found at Woodville supported earlier findings (Gillingham et al. 1998; Lambert et al. 1983). Although high mass of perennial ryegrass was associated with low Olsen $\mathrm{P}$ values at Woodville and Cheviot, the lowest values found were unlikely limiting pasture growth (Morton \& Roberts 2009). The positive canonical coefficients for $\mathrm{K}$ status at both locations and positive (Cheviot) or negative (Woodville) coefficients for Olsen P suggests variation between locations in the joint effect of these nutrients on growth of perennial ryegrass.

The effects of slope class on the abundance and growth of the sown species at Woodville and Cheviot should be interpreted cautiously because seedling and plant densities of sown species in each slope class were not measured earlier (Tozer et al. 2013; Tozer et al. 2014), including at the start of this study. Furthermore,

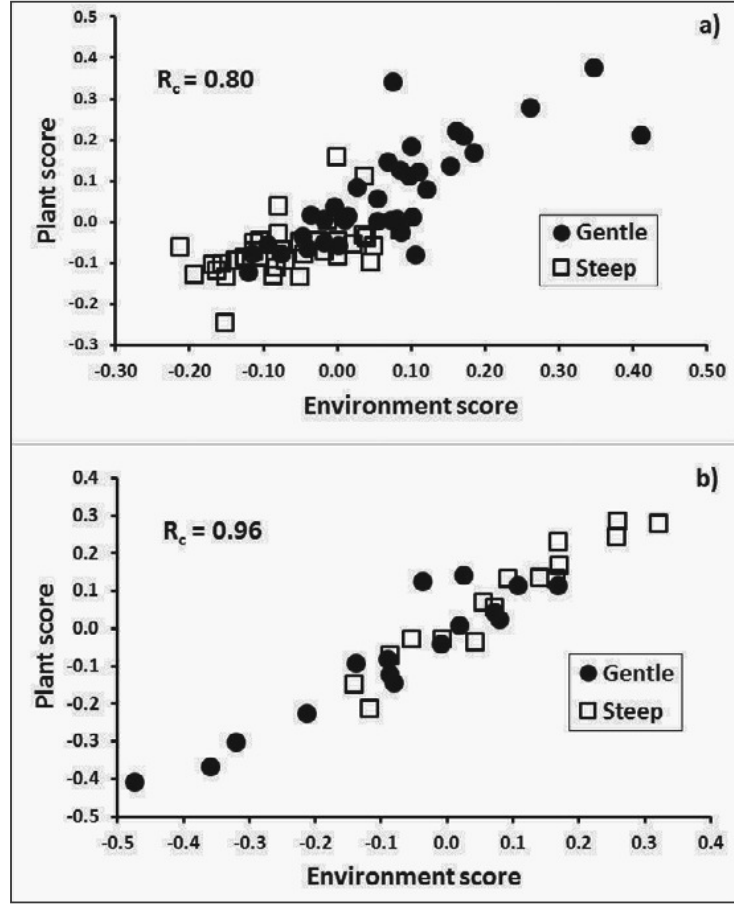

Figure 1 First canonical variate scores at a) Woodville (key plant attributes $=$ growth rate and perennial ryegrass mass (both with positive canonical coefficients); key environmental attributes = slope (negative), Olsen $\mathrm{P}$ (negative), and K (positive)) and b) Cheviot (key plant attributes $=$ masses of perennial ryegrass and dead matter (both negative); key environmental attributes (aspect, Olsen $\mathrm{P}, \mathrm{K}$ and $\mathrm{Na}-$ all negative)). $\mathrm{R}_{\mathrm{c}}=1^{\text {st }}$ canonical correlation.

potential differences in grazing of gentle and steep slopes by sheep during previous rotational grazing cycles, and other impacts of livestock such as treading damage and plant selection, could not be accounted for. The impact of the high covers at closing on species abundance was uncertain but did not invalidate the comparisons between gentle and steep slopes. The results indicated persistence of the sown species in each environment.

\section{Conclusions}

Environmental conditions varied between slopes at some or all location $\times$ aspect combinations. Perennial ryegrass and phalaris were present in a greater proportion of plots on gentle than steep slopes, whereas subterranean clover had greater presence on steep than gentle slopes. Perennial ryegrass comprised a higher $\%$ of total DM in swards on gentle than steep slopes. The lack of differences between slopes for presence and $\%$ of total DM of most sown species indicated that slope and associated environmental parameters were not significant factors influencing persistence of sown species. 


\section{ACKNOWLEDGEMENTS}

Funding from Ministry of Business, Innovation and Employment, DairyNZ, Fonterra, Beef + Lamb New Zealand and DCANZ (Dairy Companies Association of New Zealand); advice on farmer needs from Beef + Lamb New Zealand; the managers and staff on whose properties the studies were conducted at Woodville and Cheviot.

\section{REFERENCES}

Chapman, D.F.; Macfarlane, M.J. 1985. Pasture growth limitations in hill country and choice of species. Using Herbage Cultivars. Grassland Research and Practice Series 3: 25-29.

Digby, P.G.N.; Kempton, R.A. 1987. Multivariate Analysis of Ecological Communities. Chapman \& Hall, London.

Douglas, G.; Moss, R.; Knight, T.; Lloyd-West, C.; Gray, R.; Tozer, K. 2015. Microsite effects on abundance of sown species on uncultivable hill country - a preliminary report. Report prepared for P21 Science Management and Steering Group. RE500/2015/058. Report AgResearch Ltd.

Douglas, G.B.; Tozer, K.N.; Fraser, T.J.; Muir, P.D.; Moss, R.A.; Rennie, G.M.; Knight, T.L. 2013 Successful establishment of oversown chicory and plantain on uncultivatable hill country. Proceedings of the 22nd International Grassland Congress, Sydney, Australia. 15-19 September, 2013.

Gillingham, A.G.; Gray, M.H.; Smith, D.R. 1998. Pasture responses to phosphorus and nitrogen fertilisers on dry hill country. Proceedings of the New Zealand Grassland Association 60: 135-140.

Hampton, J.G.; Kemp, P.D.; White, J.G.H. 1999. Pasture establishment. pp. 101-115. In: New Zealand Pasture and Crop Science. Eds. White, J.; Hodgson, J. Oxford University Press, Auckland.
Lambert, M.G.; Clark, D.A.; Grant, D.A.; Costall, D.A. 1983. Influence of fertilizer and grazing management on North Island moist hill country. 1. Herbage accumulation. New Zealand Journal of Agricultural Research 26: 95-108.

Lambert, M.G.; Rhodes, A.P.; Barker, D.J.; Bircham, J.S. 1985. Establishing and managing improved plants in hill country. Using Herbage Cultivars. Grassland Research and Practice Series 3: 31-35.

Morton, J.; Roberts, A. Eds. 2009. Fertiliser Use on New Zealand Sheep and Beef Farms. New Zealand Fertiliser Manufacturers' Research Association, Auckland, New Zealand.

Scott, D.; Keoghan, J.M.; Cossens, G.G.; Maunsell, L.A.; Floate, M.J.S.; Wills, B.J.; Douglas, G.B. 1985. Limitations to pasture production and choice of species. Using Herbage Cultivars. Grassland Research and Practice Series No. 3: 9-15.

Stewart, A.; Kerr, G.; Lissaman, W.; Rowarth, J. 2014. Pasture and Forage Plants for New Zealand. New Zealand Grassland Association, Dunedin, New Zealand. 139 pp.

Tozer, K.N.; Douglas, G.B.; Cameron, C.A.; Fraser, T.J.; Moss, R.A.; Rennie, G.M.; Knight, T.L.; Muir, P.D. 2013. Pasture establishment on non-cultivable hill country. Proceedings of the New Zealand Grassland Association 75: 215-220.

Tozer, K.N.; Douglas, G.B.; Moss, R.A.; Rennie, G.M.; Knight, T.L.; Fraser, T.J.; Cameron, C.A.; Muir, P.D. 2014. Early performance of oversown pasture mixtures on non-cultivable hill country at four geoclimatically different sites. Proceedings of the New Zealand Grassland Association 76: 155-162.

VSN International 2014. GenStat for Windows 17th Edition. Hemel Hempstead, United Kingdom. 
